\title{
Second Level Coping Mechanism: A Study on Problem Solving Measures Taken by Street-Level Bureaucrats Concerning Agrarian Policy in Cipari, Cilacap
}

\author{
Deden Dani Saleh ${ }^{1}$ \\ Wahyudi Kumorotomo ${ }^{2}$ \\ Agustinus Subarsono ${ }^{3}$ \\ Bambang Hudayana ${ }^{4}$
}

\begin{abstract}
This article concerns the efforts carried out by lower level bureaucrats in order to implement their decisions. Prior studies generally describe the decision of street-level bureaucrats (SLBs) as decisions that have already been implemented. There have not been many studies describing the efforts of SLBs in realizing their decisions. Thus, this study intends to examine the efforts undertaken by the lowest level bureaucrats to implement the decisions they have made. The main reference used to analyze this phenomenon is by using the structural approach and the DNA of negotiation. To describe this phenomenon, the study explored a case of program implementation on land redistribution in the Cipari District, Cilacap Regency in 2010. Study results show that power, strategy, and distributive negotiation tactic, as well as personal values are key elements in implementing decisions. The results indicate that discretion is not always applicable since there are times when discretion is limited and thus it must be developed. Because this study relates to the success or failure of policy implementation, knowledge about ways of developing discretion becomes a substantial part in optimally developing public policy.
\end{abstract}

\section{Keywords:}

street-level bureaucrats; behavior; discretion; power; negotiation strategy; personal values

\section{Introduction}

This study is a study on problem solving mechanism conducted by street-level bureaucrats (SLBs) in a situation involving horizontal implementation. Problem solving mechanism refers to actions or decisions taken by SLBs when facing opposing situation in policy implementation. Michael Lipsky (2010) refers to this as coping mechanism. So far, there has not been many studies on coping mechanism describing the study in a horizontal situation. The existing studies mostly describe problem solving mechanism in a hierarchical implementation situation - wherein the clients depend on SLBs, such as: Vincent Dubois (2010 in Tummers et al. 2015) who conducted a study on the use of personal resources; Tummers et al. (2012) who conducted a study on 'bending

\footnotetext{
Sekolah Tinggi Pertanahan Nasional

2 Department of Public Policy and Management, Faculty of Social and Political Sciences, Universitas Gadjah Mada

3 Department of Public Policy and Management, Faculty of Social and Political Sciences, Universitas Gadjah Mada

4 Department of Anthropology, Faculty of Cultural Sciences, Universitas Gadjah Mada
} 
Deden Dani Saleh, Wahyudi Kumorotomo, Agustinus Subarsono, Bambang Hudayana, Second Level Coping Mechanism: A Study on Problem Solving Measures Taken by Street-Level Bureaucrats Concerning Agrarian

Policy in Cipari, Cilacap

rules'; Dorothea Anagnostopoulos (2003) on 'breaking rules'; Henrik Wagenaar (2004) on instrumental measures; or Siddharta Baviskar (2018)Copyright (C) 2018 Taylor \& Francis Group, LLC. ABSTRACT: Ideas as to how and why individuals resort to creaming are generated primarily by a few qualitative studies and have, to our knowledge, not been tested quantitatively. This article aims to fill this gap and explains the classroom creamskimming behavior of school teachers in Denmark, defined as prioritizing the teaching of academically promising students. Drawing on the street-level bureaucracy literature, it tests the following propositions: ( 1 and Katrin Križ \& Marit Skivenes (2012) who conducted studies on the priority of clients.

In a horizontal situation, the decision made by SLBs may differ. Policy horizontal situations, which are indicated by the presence of non-state actors in the policy process, make decisions difficult to implement (Budiman and Hadiz in Pratikno, 2007) - the coping mechanism that has been decided may not entirely be implemented. The approval of other actors in the policy process over a form of problem solving mechanism entails the following resolution measures that must be carried out by SLBs. The presence of non-state actors pushes SLBs to carry out subsequent problem solving mechanism in order to be able to implement the problem solving mechanism which had been decided earlier.

Essentially, this study is a study on negotiations between SLBs and non-state actors. Studies on low-level bureaucrat negotiations have been conducted numerously. One of them is a study conducted by Clarissa Marcondes Macea. In Macea's study, it is stated that negotiation practices in policy implementation may result in the program running effectively and thus the government benefits from them (Macéa, 2014). In line with Macea, Collin Eden and Fran Ackerman also suggest negotiations in the policy process. They even went so far as to suggest that the negotiation process should be conducted as a conscious process (Eden \& Ackermann, 2014)and public-public, projects are now an established way of creating public value. Establishing joint goals within a context of different 'own goals' is important and difficult. A particular issue facing many organisations in seeking to negotiate joint goals in a collaborative project is that of getting all the key managers from both organisations together over enough of a sequence of meetings for agreements to be meaningful and owned by those who will deliver the project. The development of such goals can be significantly enhanced by (1. Subsequently, a study on low-level bureaucrat negotiation that is more technicalpractical was conducted by Vicky Johansson. Johansson (2012) found that fragmented implementation structure determines when and how negotiations are conducted by SLBs. Meanwhile, this study examined SLB negotiations within horizontal implementation situation. In this case, the SLBs were not the only actors involved in the implementation process. Given the situation, the SLBs' decisions were not necessarily implementable (Pratikno, 2007). So, as mentioned by Zartman (1997), under horizontal conditions, negotiations are done not because of the fragmentation of implementation structure, but because there are other parties with sufficient power forcing their will.

Theoretically speaking, this is a significant study as it contributes new knowledge to studies on SLBs, which have thus far been positioned in a hierarchical situation. The theoretical contribution of this study lies in the extension of knowledgeable insight concerning negotiation measures carried out by SLBs. In essence, this study is a response to Vicky Johansson's study which analyzed negotiation measures of low-level bureaucrats in the infrastructure policy sector. This study concurs with Johansson that SLBs negotiate not because they choose to negotiate but 
because negotiation is considered as the best means available. Empirically speaking, this is a substantial study because it explored the case of land redistribution in Cipari, Cilacap, involving SLBs of Agrarian Reform (Reforma Agraria - RA) and client organizations. Knowledge about program implementation will be highly beneficial in implementing similar future programs. Concerning this program, the government states that there are still 9 (nine) million hectares of state land categorized as Land Objects of Agrarian Reform (Tanah Obyek Reforma Agraria - TORA), which are ready to be redistributed (Kantor Staf Presiden, 2016).

Based on the background above, the question posed is: how are the negotiations carried out by SLBs of RA in order to implement their decisions? Due to the fact that relations among state and non-state actors are closely associated with power (Baker, 2002), a structural negotiation approach is used to examine the negotiation process undertaken by SLBs of RA. This approach is a negotiation approach that observes the power of the parties involved as a key element in the negotiation process.

\section{SLBs of Agrarian Reform and Horizontal Situation}

In addition to being policy implementers, SLBs are also known as policy makers or decision makers and negotiators (Johansson, 2012). As previously mentioned, SLBs are the lowest level bureaucrats in the bureaucratic chain that are tasked in implementing (delivering) policies (Lipsky, 2010, p. 3). In conducting their daily tasks they are not inseparable from various problems, such as policies that are not necessarily compatible with varying clients and temptations originating from within their own selves (Gofen, 2014; Hupe \& Hill, 2007; Maynard-Moody \& Musheno, 2003; Sager et al., 2014). SLBs have developed particular mechanisms to address such contradictory situation and resolve them (Lipsky, 2010, p. 13). Two things allowing SLBs to employ these mechanisms are the extensive discretion and autonomy that they hold (Lipsky, 2010, p. 14).

An SLB-like role in implementing RA policy that was attached to the lowest government institution or the committee formed by this lowest level of administrative unit $^{5}$ had similarities and differences with the already well known SLBs. In terms of control, SLBs of RA had extensive autonomy. Observed from the level of administrative structure, the village government along with its personnel or redistribution executive committee were far removed from the regent (regional government) as the ruler of the regency; were far removed from the governor (provincial government); and even farther removed from the minister of home affairs; and exceedingly far removed from the National Land Agency (Badan Pertanahan Nasional - BPN) as the bearer of the land reform policy. In this case, SLBs of RA refers to an organization instead of an individual. In terms of face-toface meeting with clients, due to the village head and staff's small coverage of work area, they were able to have more intensive direct engagements with their clients. The following table shows a comparison of several attributes from SLBs that have already been studied.

One thing that is quite interesting from SLBs of RA was the client type or target group. The client type faced by SLBs of RA policy was a combination of passive and active clients. Both active and passive clients became one of SLBs' focuses of attention in decision making. Passive client in this study is defined as introduced by Lipsky, such as: students, criminals, the unemployed, or the sick are clients that the SLBs

\footnotetext{
${ }^{5}$ In the Presidential Decree No. 55/1980 on the Organization and Procedure for the Implementation of Land Reform, the executors of the land reform policy are the personnel in the ministry of home affairs, starting from the Minister of Home Affairs and staff at the national level until the village head and staff at the village level. The lowest level of bureaucratic rank and file in the land reform governance is the village head and staff. They are to be assisted by a local land office staff in establishing a land reform committee.
} 
Deden Dani Saleh, Wahyudi Kumorotomo, Agustinus Subarsono, Bambang Hudayana, Second Level Coping Mechanism: A Study on Problem Solving Measures Taken by Street-Level Bureaucrats Concerning Agrarian

Policy in Cipari, Cilacap

Table 1.

Comparison of SLBs

\begin{tabular}{|c|c|c|c|c|}
\hline & $\begin{array}{c}\text { SLBs } \\
\text { of Social Policy }\end{array}$ & $\begin{array}{c}\text { SLBs } \\
\text { of Environmental } \\
\text { Policy }\end{array}$ & $\begin{array}{c}\text { SLBs } \\
\text { of Infrastructure } \\
\text { Policy }\end{array}$ & $\begin{array}{c}\text { SLBs } \\
\text { of Agrarian Reform }\end{array}$ \\
\hline Relation & Direct & Indirect & Indirect & Direct \\
\hline Focus of Service & Individual & Collective & Collective & Individual \\
\hline Participant & Client Organization & $\begin{array}{l}\text { Government, } \\
\text { Organization }\end{array}$ & Government & Client Organization \\
\hline Target Group & Closed & Open & Closed & Open \\
\hline Profession of SLBs & Professional & Bureaucrat & Bureaucrat & Bureaucrat \\
\hline Institutional Level & Individual & Organization & Organization & Ad Hoc Organization \\
\hline Type of Client & Passive & Passive & Passive & Passive and Active \\
\hline
\end{tabular}

Source: Mikael Seva (2015) and Vicky Johansson (2012)

considered within the limit of their individual preference. Whereas, active client is defined as clients who aside from being considered by SLBs based on their individual preference are also considered by SLBs as those possessing greater power ${ }^{6}$, which is the power to reject the various decisions made by SLBs. In the policy process, even more so today, disagreements

\footnotetext{
${ }^{6}$ Horizontal situation is a policy process situation indicated by the presence of other actors aside from the state. The involvement of non-state actors in the policy process is because they have greater power than they used to (Pratikno, 2007, 2008). They are more active than the previous time periods. Within such situation, policy cannot be easily implemented (Budiman and Hadiz in Pratikno, 2007). In this situation decisions have to be negotiated (Pratikno, 2007). The horizontal condition of RA policy in Cipari, Cilacap has been established since a long time ago. If the involvement of non-state actor in the public policy process is in the form of mass mobilization, threats, and intimidations (Susskind, 2006), then horizontalism in land/agrarian policy or in policies relating to the social economic life of farmers in Indonesia has fundamentally taken place for quite a long time - since the colonial period (see Bachriadi, 2012). Citing Jonathan Fox, Skocpol, Landsberger, and James Scott, Bachriadi provides a description that forms of involvement by non-state actors in agrarian policy range from 'daily resistance', which is individual and subtle, to more flagrant forms such as collective protests, or even more extreme measures in the form of revolts or uprisings (Bachriadi, 2012). Concerning the horizontalism condition of RA in Cipari, Cilacap, Desi Rahmawati (2003) has provided a clear illustration on the formation of client organization there. Meanwhile, concerning public (client) involvement, Jarot Santoso (2016) has described what means have been employed by the Cipari, Cilacap farmers' movement to develop, continue their struggle, and ultimately influence the policy process.
}

are commonplace and negotiations as an effort to resolve issues of dissent is not uncommon as well (Fuller, 2013). For that reason, the coping mechanism produced by SLBs is not only limited to the conventional mechanism (moving toward, moving away from, and moving against), but it also entails a coping mechanism in the form of negotiation.

Under such conditions, the practice of decision making or the production of coping mechanism differs. In this situation, the problems encountered by SLBs are not only incomplete policy regulations, diverse client interests, organizational codes, and personal values, but also clients who have the power to reject decisions. After producing a particular coping mechanism, SLBs must also carry out another coping mechanism, which is negotiation with their clients - as if there were two levels of coping mechanisms (ilustrated in Figure 1).

The figure above shows that negotiations carried out by SLBs are not brought about by the fragmentation of implementation structure, but by the horizontal situation of the implementation process. Within the process, on the one hand, there are non-state actors who have the capacity to dismiss the decisions of state actors, while on the other, there are state actors who recognize that non-state actors have the capacity to say no. 
Figure 1.

Dual Level Coping Mechanism

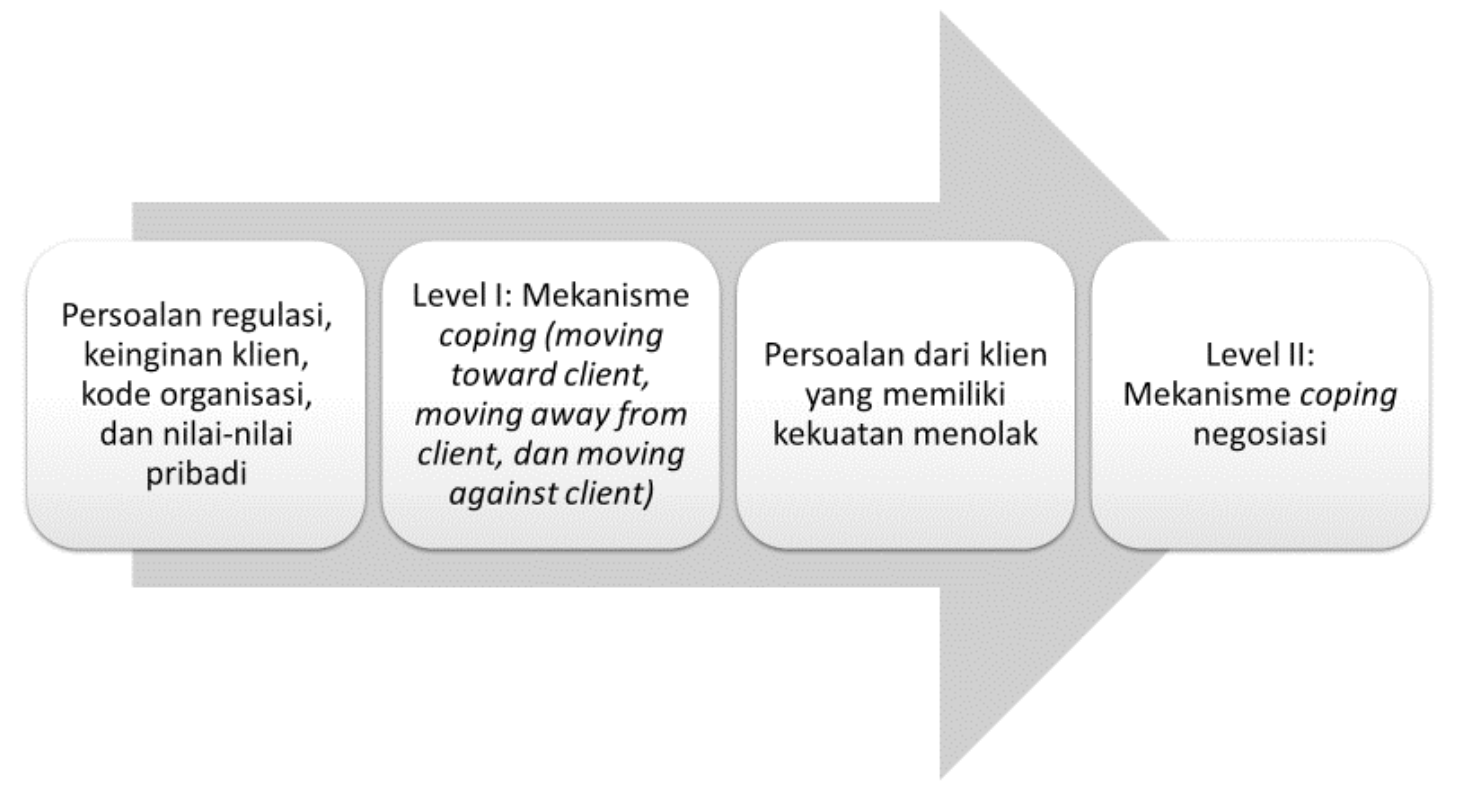

\section{Negotiation of Street-Level Bureaucrats}

In addition to being policy makers and implementers, SLBs may also function as negotiators (Johansson, 2012). According to Ray Fells (2009, p. 4) negotiation is generally defined as a process in which two parties with different interests meet, or to be precise, negotiation is a process where two parties with differences that they intend to resolve try to reach an agreement by means of exchanging offers or exploring alternatives. As a process, if negotiation were made into a structure, it would consist of antecedents that include preparation, atmosphere, and background of the negotiator; of negotiation process that include processes of creativity, persuasion, emphasizing position, overcoming deadlocks, break-up behavior, and threats; and outcome or agreement (Ott, Prowse, Fells, \& Rogers, 2016). Then, negotiation factors or elements, such as power (Fells, 2009, p. 14; Fisher, 1983; R. Lewicki, Saunders, \& Barry, 2007; Overbeck \& Kim, 2013) will start to function when the negotiation process takes place (Ott et al., 2016). In addition, strategy also holds a substantial role to achieve a satisfying negotiation outcome because it is implemented by the negotiator when the negotiation encounters a problem (Alfredson \& Cungu, 2008; R. J. Lewicki, Saunder, Barry, \& Saunders, 2007). Subsequently, once the situation has been addressed an agreement (negotiation outcome) is achieved.

Preparing oneself for a negotiation process is of utmost importance (Ury, 2007, pp. 33-46). In this stage, the negotiator is encouraged to understand his/her position and interests. A position in a negotiation process refers to something that the negotiator desires, whereas interest refers to the desire or need that motivates the negotiator (Fuller, 2013). Ury (2007) describes interest as things that revolve around position. For instance, in the Cipari land redistribution case, it was the SLBs' decision that the people who will receive land that PT. RSA formerly had the Right of Exploitation (HGU) to would be the poor community in the five villages, this is the position of SLBs, while SLBs' interest is to lift villagers out of poverty. In negotiations, knowledge about position and interests is essential as it determines the subsequent negotiation process. Positions usually do not change easily (Ury, 2007, p. 1). 
Deden Dani Saleh, Wahyudi Kumorotomo, Agustinus Subarsono, Bambang Hudayana, Second Level Coping

Power in the negotiation process is generally acknowledged as a substantial element in the negotiation process. If negotiation is defined as 'influence', aside from status, power is the main source of such 'influence' (Overbeck \& Kim, 2013). Indeed, power is not the only substantial element in negotiations (Fells, 2009). However, in this study, since relations between state and non-state actors in the policy process were strongly associated with the relative power the parties held (Baker, 2002), then the power approach was used to help analyze the negotiation situation under study. The power approach for negotiation, which is also known as the structuralist approach of negotiation, is a negotiation approach that considers the relative power among the parties involved in the negotiation process as a significant element that may drive the negotiation process (Alfredson \& Cungu, 2008).

In general, power is defined as a person's ability to make others do something he/she wants (Fisher, 1983; R. J. Lewicki et al., 2007). One of the earliest definition of power is, essentially, the ability to get what you want (Russell, 1938). The most basic form of power is physical power: using threat or inflicting bodily harm, even death, to force compliance. Since modern society generally does not favor the use of physical power, then a milder form of power is used in its stead. For instance, rather than mobilizing troops to suppress every conflict, modern governments use negotiation and political processes to achieve mutually acceptable outcomes. Therefore, negotiation is a milder power channel within itself, and the context where milder and harsher (such as, using threats) power is employed (Russell, 1938 dalam Overbeck \& Kim, 2013).

One of the criticism against the power approach is that it negates the other abilities that negotiators possess, such as communication skills (Alfredson \& Cungu, 2008). This criticism is neither entirely right nor wrong. On the one hand, it does seemingly neglect other abilities that negotiators have. Yet, studies employing the structural approach have provided rebuttals of such criticism. One of the examples is a study conducted by Frank R. Pfetsch and Alice Landau (2000). In their study it is argued that the weak party under asymmetric negotiation conditions can still gain benefits by using certain strategies (Pfetsch \& Landau, 2000). Hence, this study also elaborates on how certain strategies are used by the parties involved to fulfill their interests.

The basic concept of negotiation is strategy and tactic (Alfredson \& Cungu, 2008). A strategy is a plan or method specifically utilized to achieve an objective, while a tactic is the skill of employing various existing tools or means to achieve said objective (Alfredson \& Cungu, 2008). Numerous experts are in agreement that there are two basic concepts of negotiation, namely: distributive negotiation and integrative negotiation. The two differs in the desired outcome, which is the desire to end up in a win-lose situation (distributive) or the desire to create a win-win situation for all (integrative). If we compare them with a cake, integrative negotiation entails making the cake bigger so that each party can obtain the same big piece of the cake. Whereas distributive negotiation entails distributing the existing cake and surely each party wants the biggest piece of the cake.

How can those desires be achieved? Certain tactics are developed. Certain tactics follow the strategy applied (Weingart \& Olekalns, 2004)"title":"Communication Process in Negotiation: Frequencies, Sequencies, and Phase","type":"chapter"],"uris":[“http://www. mendeley.com/documents/?uuid=dfd03d1c122e-4198-bffc-c43380d4ac7f"]\}],"mendeley": \{“formattedCitation":"(Weingart \& Olekalns, 2004 . Since competitive strategy leads to a winlose outcome, many (particularly those in favor of the integrative school) consider such strategy as destructive (Alfredson \& Cungu, 2008). In this case, Raymond Saner (2004) has identified several tactics or attributes of distributive 
negotiation tactics, such as: coercive: use of force or threats; opening strong: start negotiations by campaigning positions; and subtly such as by prolonging the negotiation process or providing minimum concessions.

After employing these strategies and tactics, there are consequential behaviors or actions brought about by the implementation of those strategies and tactics. This is the negotiation agreement or outcome. Negotiation is a goal oriented activity and every negotiation ultimately produces an agreement, either satisfying or not (Fells, 2009, p. 4). According to Ray Fells (2009, p. 36), the core of integrative negotiation is that both sides gain something and are happy with their agreement. Satisfied with the outcome, they would be more committed to implement the outcome unreservedly and more positive about the relationship they have with the other party. This will help facilitate future negotiations among them. This is different from distributive negotiation wherein one or both parties do not gain anything from the negotiation, as a result they would be uncommitted to the agreement and disliked by the other party. This shows that consequences of choosing certain strategy lie in the implementation of the agreement.

\section{Methods}

The empirical case examined in this study is the implementation of the land redistribution program in Cipari District, Cilacap Regency. The land redistribution was fully implemented by mid 2010 with the distribution of land that PT Rumpun Sari Antan (RSA) formerly had the Right of Exploitation (HGU) over to 5,141 heads of household from five villages (Caruy, Mekarsari, Sidasari, Kutasari, and Karangreja) in the district. The program implementer at the regency level was known as the (Spatial) Arrangement Team and the Technical (Spatial) Arrangement Team for the Ex-HGU Land of PT RSA; at the district level they were known as the Monitoring and Supervising Team for Taking
Inventory and Data of Cultivators on the ExHGU Land of PT RSA; and at the village level it was known as the Team for Taking Inventory and Data of Cultivators on the Ex-HGU Land of PT RSA. The two teams of the regency and the district were only tasked to monitor and provide consultations for the village team.

The village team, which directly dealt with the target group, is what we consider as SLBs and they are the respondents in this study. The number of team members in each village varied. The initial standard for the number of respondents is based on the report made by the Cipari District Head to the Cilacap Regent. It was reported that there were 60 members in the district and village teams. The total member of the village team was 53 people. Hence, there were 53 respondents in this study. They were the members of the village team who were examined in this study based on face-to-face meetings with the clients, and the people who did indeed directly meet the clients.

Information were obtained through interviews and in-depth interviews. In-depth interviews were conducted with people from the team who are considered more knowledgeable than their colleagues. They are considered as key informants. Meanwhile, interviews were conducted with other respondents to confirm the information conveyed by the key informants. By paying close attention to the depth of information conveyed, the amount of key informants in this study was then determined, i.e. 4 individuals. The technique employed was by asking the key question 'why was the amount at 5,141?' If the response given was a description that is lengthy and informative, then that respondent's information would be considered as worth using. By using this technique, as many as 5 key informants were obtained, in which two of them were SLBs and three were clients. Then, as a triangulation measure, the information acquired from the key informants were confirmed to several other respondents, in which at least 17 of them 
were consulted. Using the same key question, about 8 people answered in line with the information obtained from the key informants. The interview process was conducted in three stages. Every stage of the interview was done with a long time span between them. The first stage was called the introduction stage. The second and third stage was called the deepening stage or it can also be considered as the effort to confirm the existing responses.

Subsequently, the gathered information was managed as is commonly done by qualitative study, up to the point where the findings are then presented as in the following passages.

\section{Results}

The low level bureaucrats of Agrarian Reform policy are considered as bureaucrats that negotiated not because they chose to negotiate but because they were in a situation of disagreement with other actors in the policy implementation process. According to the definition of negotiation provided by Ray Fells (2009, p. 4), negotiation takes place when two parties with differences try to resolve their differences by exchanging offers or exploring alternatives to ultimately reach an agreement, and based on this, the negotiations the SLBs of RA conducted with the other party were the SLBs' efforts to obtain the agreement of other actors regarding the decision they have made and vice versa. From the Cipari RA case, the SLBs' focus of negotiation was to carry out the decision that has been made. Whereas the focus of the other party is to fulfill their desire. The two differing focuses had lead to a deadlock. However, concurrently the SLBs also applied various tactics in the strategy they made. On the other hand, there were internal factors in the opposition that contributed in paving the way for negotiations, in which ultimately one of the party left the negotiation.

Basically, this section describes the efforts of RA SLBs to get their clients and organizations to agree with the decisions they made. The decisions made by the Cipari RA SLBs in order to implement land redistribution at the time were: (1) the clients must pay compensation fee; (2) negotiate the compensation amount with the company; (3) the clients are the cultivators and the poor; (4) the size of land is distributed equally; (5) accommodate residents from outside the district; (6) provide bailout for compensation cost; and (7) provide one plot of land to the head of the committee. Two ( 1 \& 3 ) of the decisions were rejected by the clients and their organization. The rejection was based on various reasons, such as: since the start of their struggle/advocacy not a word of 'paying compensation fee' was mentioned; if payment were made, it would be akin to creating a 'market for land'; and since the beginning, since a long time ago, the farmers who advocated for the right to own land were cultivators who had either passed or still lived in or outside of Cipari.

The rejection dragged on for about two years, from 2008 when negotiation efforts carried out by the association of village heads and the plantation company were found out by the clients and their organization until 2010 when the payment for the compensation fee was executed. It is this two-year period which is regarded as the process of negotiations between Cipari RA SLBs and the clients along with their organization.

\section{a. Negotiation Preparation}

The negotiations carried out by Cipari RA SLBs were not formal negotiations where both parties sit together, exchanging offers finding an alternative, and then arriving at an agreement. The negotiations conducted by Cipari RA SLBs were not different to real life actual negotiations, like: a child asking for a particular toy and whining to their parents then eventually the parents would buy it for them. The negotiations that Cipari RA SLBs carried out were things that others would do 
when they are put in the same position. Thus, the preparation stage in the Cipari RA SLBs negotiations was the stage in which various information or preferences of the respective parties were able to be conveyed.

Given that, commonly, the preparation process is indicated by the unravelling of positions into interests, the process of negotiation preparation that Cipari RA SLBs undertook can be considered as a bad one. Both parties were able to state another alternative when asked what if their desire was not accommodated by the SLBs or was still rejected by the clients. As one of the key informants mentioned: "what else can you do...the rule is already set"; "it's very reasonable for an owner to ask for compensation for something handed over to another person". One of the key informants from the client side also said the same: "there shouldn't be any compensation given for that land because if there were then a market for land would ensue".

In terms of information exchange, the preparation process can be considered as bad. Exchange of information occurred unilaterally. As admitted by the key informant from the SLBs, he/she has known about the wish of the clients and client's organization since a long time ago. The key informant said that he knew the activities of the farmer organization members by heart, how they carry out their protests, and how they engage in communication during their protests or meetings. On the contrary, the clients did not clearly know the interests of the SLBs. "I was rather surprised when I heard that the village head association has conducted meetings with the plantation company".

The processes or struggle of the farmer's movement through protests and then followed by forming farmer organizations in every village (Santoso, 2016) can also be considered as an effort to build up power. At the very least, the power structure the clients possess had already been established when the negotiation process took place. The statement that validates this is as follows: "we are also afraid to take a step because there is the possibility that it would suddenly be reported in the newspaper". This statement came up when the discussion continued to the topic that those meetings with the company were conducted without the facilitation of other parties. The meetings took place purely through the use of personal resources.

\section{b. Use of Power}

The power that each party wields in a negotiation process can be more easily explained from one of the party's origin of power. According to Roger Fisher (1983), the power wielded by the negotiating parties is a totality of power sources that originate from: skills and knowledge, good relationship, good alternatives, elegant solutions, legitimacy, and commitment. Both parties involved in the Cipari RA negotiations did not have good power. Each party had an incomplete source of power. The SLBs of RA had power from legitimacy, but they did not have power originating from good alternative. This was also the case with the clients. The clients had power originating from good relationship with other parties but they had no good alternative as well (summarized in table 2). The following table provides a detailed account on the power that each party had in the Cipari RA negotiation.

Table 2.

The Comparison of Power Sources

\begin{tabular}{lcc}
\hline & $\begin{array}{c}\text { Cipari RA } \\
\text { SLBs }\end{array}$ & $\begin{array}{c}\text { Cipari RA } \\
\text { Clients }\end{array}$ \\
\hline Skills and knowledge & Yes & Yes \\
Good relationship & Yes & No \\
Good alternatives & No & No \\
Elegant solution & No & No \\
Legitimacy & No & Yes \\
Commitment & No & No \\
\hline
\end{tabular}

Source: Research results

Another issue relating to power is how the parties utilize or benefit from their power. The SLBs' power, which came from their self 
Deden Dani Saleh, Wahyudi Kumorotomo, Agustinus Subarsono, Bambang Hudayana, Second Level Coping Mechanism: A Study on Problem Solving Measures Taken by Street-Level Bureaucrats Concerning Agrarian

Policy in Cipari, Cilacap

legitimacy as village head, allows themselves to determine the negotiation objective they want to achieve. The following box is an excerpt from an interview with an informant. In the box, it is interesting to note that there was the issue of an SLB's 'conviction in a particular means of resolution'. This was a belief held by one of the RA SLBs, and due to the SLB's administrative position as village head, the issue was raised and became an issue of the SLB organization as a whole.

Box 1.

Resident Must Pay Compensation

\section{Box \\ Residents Must Pay Compensation}

...actually no one believed that the PT. RSA HGU conflict or program will finish. Conflict resolution efforts have been carried out for a long time. Other village heads have tried to resolve this conflict to no avail. The former village heads reminded me to try and resolve this problem. That's why since I became a village head candidate I promised to resolve this issue and help the community's struggle concerning the HGU conflict. The only way that I believe can resolve this conflict is that there must be compensation fee given to PT. RSA. It's very reasonable if the former land owner asks for compensation fee and it is already in line with the existing regulation and the BPN (National Land Agency) also said so.

Source: interview with former village head of Karangreja, December 2017 and April 2018.

Another use of power demonstrated by the SLBs was the power to form the RA implementation executing organization. RA SLBs legitimacy as village heads allowed them to select people who would help in carrying out activities. The committee, which was required by the regulation, seemed to function as an institution that facilitated the use of their power. In one of the RA SLB's interview, it was admitted that he/she purposely included clients who were members of the farmer organizations and felt helped by such process, as revealed by one of the informants: "they are indeed skillful and intelligent when they talk, but once we embraced them...they became silent".
Whereas on the side of the clients, the use of their 'power', which originated from their relationship with other parties, along with their existing knowledge was not explored properly by the owner. Their power, which originated from knowledge and skills, was only used when they showed their disagreement against the decisions of the RA SLBs during meetings, as revealed by an informant: "when they started talking...all kinds of regulations were mentioned" and even this had become a boomerang when they used speech that was considered inappropriate when they delivered their arguments. This was also stated by an informant: "how are we to respect them if their way of speaking is indecent...words like helper or slave of the society was often mentioned".

Another 'power' that the clients had not explored or to be precise had not been aware of was the power they had from their good relations with other parties (in this case NGOs or even the highest official of BPN at the time). As mentioned earlier, one of the SLBs' reluctance to immediately execute their decisions was their fear of the clients making the RA SLBs' decision-making method go viral via mass media. In this context, actually, the SLBs only considered that the clients have the capacity to take numerous measures that can put the RA SLBs at a disadvantage. While in fact, that was the real 'power' that the RA SLBs were most fearful of and the implementation of their decisions had only been applicable after more or less two years of negotiation process.

\section{c. Strategy and Tactics}

Based on the previous description, it is explained that the power each party had in the Cipari RA negotiation was essentially equal, at least within the two-year period it was. On the one hand, one side was ultimately able to implement various decisions while the other party, the clients, had the capacity to reject them, and these two activities had led to a 'deadlock' in the negotiation for two years. 
However, during the two years, both sides did not remain silent. Particularly the SLBs, they were engaged in making strategies as indicated through several of their more obvious tactics.

One of the tactics employed by RA SLBs was the organization tactic. This study considers the tactic of enrolling clients to become organization member as an organization tactic. This tactic was feasible because, firstly, the rule or regulation did indeed stipulate the formation of an implementing organization for the land redistribution program, and secondly, the formation of the implementing organization turned into a facility utilized by RA SLBs to weaken the clients' solidarity. Aside from being 'embraced to silence' as mentioned earlier, the organizational function of the clients who were made into committee members had thwarted the clients' dissents. The clients' discontent against SLBs' decisions, which was realized by slowing down activities, was unraveled when there was a client who became an organization member. The compliance of organization members had emerged within the clients' self through their 'desire to promptly finish their job'. This is revealed from the response given by one of the respondents who stated that their task must immediately be completed so that the job is quickly over with. The organization tactic was also employed for organizations above the SLBs. This was also influential to the condition of the clients' solidarity. The clients, particularly the clients' organization was made into a member of the district level committee. The principle 'embrace to moderate' was also used in forming the district level implementing organization.

Another tactic employed by the SLBs was the tactic of using the power of others. In this case, SLBs engaged in a relationship with the National Land Agency (Badan Pertanahan Nasional - BPN) to immediately conduct sketch measurements of the area since the applicant data was already complete. This tactic destroyed the clients, particularly the leader of the farmer organization SeTam. The statement of the leader of SeTam when talking about 'BPN came and measured land areas': "yes, well, if that's what Mr. Joyo wants". Then the informant also mentioned what Joyo Winoto said to him "that's enough mbah (common honorific for elderly; grandfather/ grandmother), now the people already have their right of ownership...later, about the (land) certificate, we will try to get it without having to pay". This study interprets the situation above as follows: the clients or clients' organization had indeed become extremely powerless since the only power the clients had at the time had turned and supported the SLBs.

Another tactic that should be mentioned is a tactic employed by the clients. As the clients' solidarity was being gradually worn down, the clients also employed their own tactics, which is a kind of salami tactic, by prolonging the process. What the clients had done was prolonging the time to finish the job they have been instructed with. This occurred while they were taking inventory and data at Mekarsari village. According to one of the informants, this village has always been the basis for farmer organization in Cipari, he stated: "at the time, the work in that village had always been the last one to finish compared to the other villages". Although this remained unconfirmed, it shows that there were certain measures carried out by the clients that succeeded in affecting the duration of the program's implementation.

\section{d. Negotiation Outcome}

The negotiation outcome is an agreement that may or may not satisfy one of the party. It is an undeniable fact, however, that land distribution was done and given to 5,141 residents from five villages in Cipari District. This amount is indicative of how SLBs' interest was fully implemented. This happened because the clients pulled out of the negotiation process. Evidence indicating that the clients have pulled out of the negotiation process is the statement: "yes, well... if that's what they want" with an additional statement: "if anything happens don't blame me". This statement was repeatedly heard 
Deden Dani Saleh, Wahyudi Kumorotomo, Agustinus Subarsono, Bambang Hudayana, Second Level Coping Mechanism: A Study on Problem Solving Measures Taken by Street-Level Bureaucrats Concerning Agrarian

Policy in Cipari, Cilacap

from one of the farmer organization's leaders. There was a moment following a discussion and conversations relating to the execution of land distribution where the leader of the farmer organization said something while looking afar with teary eyes: "if I keep thinking about it, I also regret why it could end up like that". I think that this is an indication that the land redistribution in Cipari, Cilacap was a mistake.

Aside from the tactics employed by the SLBs and the clients, the withdrawal of the clients from the negotiation was influenced by several factors, namely: personal values, social cohesion values, and group stamina. Personal values were shown through the statement of one of the informants that he/she has argued with a lot of people for a long time and he/she no longer intends to argue with his childhood friend any longer. The statement he/she made: "do I also have to be at odds with my own friends $n o w$ ". Social cohesion values were shown through the statement that he/she carries along the interest of many people, their interest relied on him/her, meanwhile, that person's neighbor had gained the same thing that they have been struggling for all this time. The leader of the farmer organization merely contemplated, could it be that they too become suspicious of each other. The statement he/she made: "what do we do Mbah". Lastly, in relation to organization stamina there was a statement that the struggle of farmer cultivators has continued since a long time ago and it will not achieve any outcome if it is not completed: "I am tired...I have fought for a long time...perhaps now it should be ended". Hence, based on those statements, the negotiation agreement of Cipari RA SLBs with the clients ended satisfactorily for the SLBs and discontentedly for the clients, particularly the leader of SeTam farmer organization.

\section{Discussion}

Basically, the negotiation conducted by SLBs with the clients or the clients' organization was to negotiate their position. According to
William Ury (2007) this kind of negotiation is difficult, even impossible. The SLBs held the position that their decision be implemented and followed, while the clients held the position that their desire be accommodated by the SLBs. However, due to the power that each of the party involved had, the negotiation was able to keep going.

The negotiation did indeed continue, but it was not one that ran on the basis of good preparation. Poor negotiation preparation rendered the interests of each party unrecognized by the parties. The lack of narrative concerning the interests of the negotiating parties indicates how bad the negotiation preparation was done. This condition substantiates the proposition made by Ursula Ott et al. (2016) that good preparation will guarantee good exchange of information and it will pave the way for the emergence of creativity and ultimately produce satisfying outcome. The outcome of this negotiation failed to satisfy one of the parties. As mentioned by Ott et al. (2016) good preparation will also resolve deadlocks and eventually achieve satisfying negotiation outcome. In the context of Cipari RA negotiation, the proposition Ott et al. made has been revalidated because the preparation that was based solely on power had ultimately ended up in a deadlock.

As a coping mechanism, negotiation in the public policy process is an unavoidable activity, since in the policy process itself multiple actors are involved. At the same time, the actors bring their own interest as well as has various social, economic, cultural, and other backgrounds. Thus, all of the diverse interests need to be articulated, as a form of the actor's actions in the policy process. In the negotiation process, of course there will be two possibilities faced by the parties (actors), as the winner or as the losers. In this context, the parties who become the winner in the negotiation process are highly considered to have control over on more resources. The winner parties manage 
all the resources productively to well support the negotiation process. On the other hand, the parties who loose during the negoatiation process are assumed to have fewer resources and therefore they cannot productively support. Consequently, the interests of the parties (actors) who win the negotiation process then applied as the basis for decisionmaking as a result of the negotiation process.

In the perspective of public policy, there is a polarization of the experts opinions for the negotiation process in a public policy. Some experts argue that negotiation is inevitable activities in the public policy process, and it is basically positive. Conversely, others expressed that the negotiation activities have a negative nature due to the various interests of each actor involved. This latter arguments provide a framework of thought that negotiation activities in a public policy should be avoided as much as possible. This study does not take the position in either one of the opinion of the expert about the negotiation mentioned above. The study has more focus on how to construct the reality of negotiations in public policy process by the street-level bureaucrats. The results of this research show that the negotiation process has succeeded in completing the stages of the asset legalization policy as part of the Agrarian Reform policy in Indonesia. However, the negotiation activities have been inadequately implemented, since there are actors who dominates i.e. the state actors, and who are in an subordinated position in the negotiation processi i.e. non-state actors such as farmers affiliated in the community movement. The overall descriptions on the above mentioned negotiation process develop a new and even wider persepctive on the knowledge of negotiation behaviors as well as its various consequences.

\section{Conclusion}

This study, ultimately, finds that distributive negotiation, or in other words, second level coping mechanism is influenced by the relative power among the parties involved. The effect of this power had led the negotiation process to a momentary deadlock. By using 'power' some of the parties chose a distributive negotiation strategy to break the deadlock, and it was indeed broken by means of one of the parties withdrawing from the negotiation process.

This study concluded that negotiation is one form of the problem solving mechanism implementing by the street level beaurecrats (SLBs). The description of the mentioned coping mechanism is a slightly different from the mechanisms previously introduced. The problem solving mechanism by the SLBs on the agrarian reform in Cipari Cilacap is a mechanism for a problem solving in the next stage after the SLBs decided a solution of the problems in the implementation. This shows that SLBs discretion is basically not something inherent but must be fought so that it can be realized.

\section{References}

Alfredson, T., \& Cungu, A. (2008). Negotiation Theory and Practice: A Review of the Literature. Roma: EASYPol. doi: 10.1007/ BF01000607

Anagnostopoulos, D. (2003). The New Accountability, Student Failure, and Teachers' Work in Urban High Schools. Educational Policy, 17(1), 119-135. doi: 10.1177/0895904803254481

Bachriadi, D. (2012). Gerakan Sosial Pedesaan sebagai Politik: Sebuah Kacamata Teoritik. In D. Bachriadi (Ed.), Dari Lokal ke Nasional kembali ke Lokal: Perjuangan Hak Atas Tanah di Indonesia. Bandung: Agrarian Resource Center.

Baker, G. (2002). Civil Society and Democratic Theory: Alternative Voice. London \& New York: Routledge Taylor and Francis Group.

Baviskar, S. (2018). Who Creams? Explaining the Classroom Cream-Skimming Behavior 
Deden Dani Saleh, Wahyudi Kumorotomo, Agustinus Subarsono, Bambang Hudayana, Second Level Coping Mechanism: A Study on Problem Solving Measures Taken by Street-Level Bureaucrats Concerning Agrarian Policy in Cipari, Cilacap

of School Teachers from a Street-Level Bureaucracy Perspective. International Public Management Journal, 0(0), 000. doi: 10.1080/10967494.2018.1478918

Dubois, V. (2010). The Bureaucrat and the Poor: Encounters in French welfare Offices. Surreys, United Kingdom: Ashgate Publishing.

Eden, C., \& Ackermann, F. (2014). 'Joined-Up' Policy-Making: Group Decision and Negotiation Practice. Group Decision and Negotiation, 23(6), 1385-1401. doi: 10.1007/s10726-013-9375-1

Fells, R. (2009). Effective Negotiation From Research to Results. doi: 10.1017/ CBO9780511841491

Fisher, R. (1983). Negotiating Power: Getting and Using Influence. American Behavioral Scientist, 27(2), 149-166. doi: 10.1177/000276483027002004

Fuller, B. W. (2013). Disagreement and Alternative Dispute Resolution in the Policy Process. In E. Araral.Jr, S. Fritzen, M. Howlett, M. Ramesh, \& X. Wu (Eds.), Routledge Handbook of Public Policy (pp. 347-360). New York: Routledge Taylor and Francis Group.

Gofen, A. (2014). Mind the Gap: Dimensions and Influence of Street-Level Divergence. Journal of Public Administration Research and Theory, 24(2), 473-493. doi: 10.1093/ jopart/mut037

Hupe, P., \& Hill, M. (2007). Street-level Bureaucracy and Public Accountability. Public Administration, 85(2), 279-299.

Johansson. (2012). Negotiating Bureaucrats. Public Administration, 90(4), 1032-1047. doi: 10.1111/j.1467-9299.2012.02025.x

Kantor Staf Presiden. (2016). Strategi Nasional Pelaksanaan Reforma Agraria 2016 - 2019. Jakarta: Kantor Staf Presiden.

Križ, K., \& Skivenes, M. (2012). How child Welfare Workers Perceive Their Work with Undocumented Immigrant Families: An Explorative Study of Challenges and
Coping Strategies. Children and Youth Services Review, 34(4), 790-797. doi: 10.1016/j.childyouth.2012.01.004

Lewicki, R. J., Saunder, D. M., Barry, B., \& Saunders, D. M. (2007). Negotiation Readings, Exercises, and Cases Seventh Edition (Seventh Ed). New York: McGraw-Hill Education.

Lewicki, R., Saunders, D., \& Barry, B. (2007).

Essential of Negotiation. McGraw-Hill Irwin.

Lipsky, M. (2010). Street-Level Bureaucracy: Dilemma of the Individual in Public Services. New York: Russell Sage Foundation.

Macéa, C. M. (2014). Applying Negotiation Skills in the Design of Public Policies: Analysis of the City of São Paulo' s Invoice Program. Sao Paulo.

Maynard-Moody, S., \& Musheno, M. (2003). Cops, Teachers, Counselors: Stories Form the Front Lines of Public Service. Michigan: The University of Michigan Press.

Ott, U. F., Prowse, P., Fells, R., \& Rogers, H. (2016). The DNA of Negotiations as a Set Theoretic Concept: A Theoretical and Empirical Analysis. Journal of Business Research, 69(9), 3561-3571. doi: 10.1016/j. jbusres.2016.01.007

Overbeck, J. R., \& Kim, Y. K. (2013). Power, Status, and Influence in Negotiation. In M. Olekalns \& W. L. Adair (Eds.), Handbook of Research on Negotiation. Cheltenham UK \& Northampton MA, USA: Edward Elgar Publishing Limited. Pfetsch, F.R., \& Landau, A. (2000). Symmetry and Asymmetry in International Negotiations. International Negotiation, 5(1), 21-42. doi: $10.1163 / 15718060020848631$

Pratikno. (2007). Governance dan Krisis teori Organisasi. Jurnal Kebijakan dan Administrasi Publik, 11(2), 121-138.

Pratikno. (2008). Manajemen Jaringan dalam Perspektif Strukturasi. Jurnal Kebijakan dan Administrasi Publik, 12(1), 1-19.

Rahmawati, D. (2003). Gerakan Petani dalam Konteks Masyarakat Sipil Indonesia: 
Studi Kasus Organisasi Petani Serikat Tani Merdeka (SeTam). Jurnal Ilmu Sosial dan Ilmu Politik, 6(3), 329-358.

Sager, F., Thomann, E., Zollinger, C., Der, N. Van, Sager, F., . . . Mavrot, C. (2014). Street-Level Bureaucrats and New Modes of Governance: How Conflicting Roles Affect the Implementation of the Swiss Ordinance on Veternary Medicinal Products. Public Management Review, 16(4), 481-502.

Saner, R. (2004). The Expert Negotiator: Strategy, Tactics, Motivation, Behaviour, Leadership (2nd ed.). Leiden - Boston: Martinus Nijhoff Publisher.

Santoso, J. (2016). Gerakan Petani dalam Menuntut Hak Atas Tanah. Yogyakarta: Universitas Gadjah Mada.

Seva, M. (2015). The Decisive Role of Street-Level Bureaucrats in Environmental Management. Swedia: Lulea University of Technology. Susskind, L. (2006). Arguing, Bargaining, and Getting Agreement. In M. Moran, M. Rein, \& R. E. Goodin (Eds.), The Oxford Handbook of Public Policy (pp. 269-295). New York: Oxford University Press.
Tummers, L., \& Bekkers, V. (2012). Discretion and its Effects: Analyzing the Experiences of Street-Level Bureaucrats during Policy Implementation. In H. Saetren \& P. Hupe (Eds.), PSG XIII: On Public Policy (pp. 5-8). Bergen, Norway: Dept. of Public Administration Erasmus University Rotterdam.

Ury, W. (2007). Getting Pass No: Negotiating in Difficult Situation (Revised). New York - Toronto - London - Sidney Auckland: Bantam Books. Retrieved from https://play.google.com/books/ reader?id=sS2amtSiHYQC\&pg=GBS.PR2 Wagenaar, H. (2004). "Knowing" the Rules: Administrative Work as Practice. Public Administration Review, 64(6), 643-656. doi: 10.1111/j.1540-6210.2004.00412.x

Weingart, L. R., \& Olekalns, M. (2004). Communication Process in Negotiation: Frequencies, Sequencies, and Phase. In M. M. Gelfand \& J. M. Brett (Eds.), The Handbook of Negotiation Culture. New York: Stanford Business Books.

Zartman, I. W. (1997). The Structuralist Dilemma in Negotiation. Research on Negotiations in Organizations, 6(January), 227-245. 